\title{
TREASURES ON THE SHELVES
}

\author{
TIM T. TOKARYK, Royal Saskatchewan Museum, Wascana Park, Regina, \\ Saskatchewan. S4P 3V7
}

One of my biggest passions is visiting book stores. The dusty shelves, books stacked any way imaginable, titles that few people find useful, but someone, sometime, will. I get less of a thrill in the new book stores not because the current titles are unexciting but because the cost of new books makes my wallet scream in fright and anger. No, it's the used more specifically the antiquarian book stores that grab my interest because, for me, the only place to search out topics related to evolution is on the shelves of antiquarian book stores.

As I enter the shop I'm initially drawn to the science section. Evolution has many avenues of thought geology, biology, paleontology. Yet even after I have gorged myself in this small area of the shop I look around and see more subjects in the distance, more volumes with the thin veil of dust that temporarily entombs them. I walk further on.

The law section has some interest to me. If you ever talk to a lawyer who happens to be somewhat familiar with the history of his or her profession mention the name Clarence Darrow. In a biography of Darrow (1857-1938), Irving Stone summarized his life "as a lawyer who attacks boldly and loudly, crosses swords even with the judge, spilling his sarcasm over the courtroom ... defending causes and beliefs so un- popular they shock many people."17 Darrow is remembered as saying, "I may hate the sin but never the sinner." ${ }^{17}$ He reached national fame a few times but none so prominently as when he defended John $T$. Scopes. Scopes was a school teacher in Tennessee who volunteered to test a little known point in state law where it prohibited "the teaching of the Evolution Theory in all Universities, Normals, and all other public schools of Tennessee which are supported whole or in part by the public school funds of the state ... [in contradiction to] any theory that denies the story of the Divine Creation of man as taught in the Bible." ${ }^{17}$ Darrow's legal opponent was William Jennings Bryan, threetime presidential candidate and fundamentalist; together Bryan and Darrow made this trial a national event. In the end Scopes was found guilty (there was never any doubt that he had violated the letter of the law but the defence wanted to prove that the law infringed on free thought, hoping later to take the case to the Supreme Court, but were never able to). Scopes was given a modest fine, but not before Darrow showed how illogical the concept of Divine Creation is in a science classroom if you go by the letter of Genesis. One can find a sufficient review of the above case by Ray Ginger in Six Days or Forever? $^{7}$

Moving to another aisle in the book 
store and taking temporary leave of nonfiction, one may find a play by Jerome Lawrence and Robert Lee called Inherit the Wind. ${ }^{10}$ Here is a theatrical production of the Scopes trial. Later Spencer Tracy and Gene Kelly headlined a powerful and still captivating movie version of the same work.

There is no doubt that the theme of evolution has touched English literature. William Leatherdale reviewed this idea and concluded that no other revolution in modern science has affected literature as much as Darwinian evolution. ${ }^{11}$ Its fundamental message seeps into almost everything. Authors like Bernard Shaw in Back to Methuselah, first published in 1921, and more recently John Fowles' The French Lieutenant's Woman, first printed in 1969, used the Darwinian thinking as a tool for social reformation in the 19th century. ${ }^{5,15}$ Tennyson and Hardy are other noteworthy authors cited by Leatherdale.

One name not mentioned (and I could never really figure out why) is Sir Arthur Conan Doyle or his famous fictional consulting detective Sherlock Holmes, since the process of deduction and the securing of facts were fundamental to Holmes and Darwin. I asked the question about Doyle to a colleague of mine, William Sarjeant of the University of Saskatchewan. Amongst his many talents, Sarjeant is also a Holmesian scholar and pointed out a passage in one of Doyle's tales. When Watson recounts his first days with Holmes in The Study in Scarlet, Holmes says, "It is of the highest importance, ... not to have useless facts elbowing out the useful ones." ${ }^{\text {"। }}$ । guess if it wasn't directly related to a case it becomes extraneous. However, one biographer of Doyle, Hesketh Pear- son, suggests that the agnostism that erupted in the latter part of the 19th century, due somewhat to the writings of Huxley and Darwin, did help shape Doyle's early years. ${ }^{12}$ [Though Holmes makes no reference to Darwin another scholar of biology, Baron Georges Cuvier, is mentioned in "The Five Orange Pips." One of the founders of comparative anatomy and a devout anti-evolutionist, Cuvier could reconstruct an extinct animal based on its fragmentary remains in the rock. He was able to achieve this not by some magical power but by his own accumulated knowledge of the form and function of extinct and extant animals. According to Holmes, "Cuvier could correctly describe a whole animal by the contemplation of a single bone, so the observer who has thoroughly understood one link in a series of incidents, should be able to accurately state all the other ones, both before and after." $]$

We could even extend our evolutionary thematics to art (something I know as much about as fiction which isn't really saying much). Martin Rudwick's Scenes from Deep Time is a compilation of early representations of the prehistoric world, most of which were originally plates in books going back to the 18 th century. ${ }^{13}$ The combination of early interpretations, primitive printing techniques, and a style of illustrating that is almost forgotten, all reflect our ontogenetic knowledge.

Charles Knight was also an artist of some repute. Most of his work was originally intended not as a supplement to the text in a book but for a bigger spectrum - the museum gallery (you can see some of his work later reproduced in many paleorelated books). The earlier part of this century saw a boom not only in 
fossil collecting but in displaying the fossils, which in turn required appropriate art work to bring home the reality of these Phanerozoic behemoths. A leader in this field was the American Museum of Natural History in New York. Knight soon became the foremost illustrator of his time, producing murals for the museum in New York as well as the Chicago Field Museum and the Los Angeles County Museum. With all the revisionism that has occurred in museum galleries over the past few decades I am not certain if most of Knight's work can be seen by the public. Fortunately, in 1982, Sylvia Czerka and Donald Glut compiled examples of Knights work in book form, Dinosaurs, Mammoths and Cavemen. ${ }^{2}$ The images may be familiar.

Often tucked away in some small nook in the book shop one will find the philosophy section. If you are lucky you may find a book or two that will have some brief discussion of science and biology. Though there has never been a shortage of philosophers, most attempts at systematic examination of science and its more profound meanings usually begin and end with physics or mathematics. Physicist and Einstein biographer Philipp Frank in his Philosophy of Science paid only nominal attention to Darwinian evolution amongst its nearly 400 pages. ${ }^{\circ}$ Thomas Kuhn's The Structure of Scientific Revolutions, considered by many to be a foundational philosophical treatise on science, has an almost equal attention span for evolution. ${ }^{9}$ Yet, if you look closely at 19th century writing, specifically Darwin, Lyell, and Huxley you are sure to find something that appeals to the sector of the brain that mulls over grander thoughts. Contemporary philosophers like Michael Ruse have upgraded biology and specifically evolution to an equal level of philosophical standing with the other, more aged sciences with Darwinian Paradigms and The Darwinian Revolution. $^{14,75}$

Religion is a favourite haunt of mine in the antiquarian book store. In general, I am interested in how science has melded or clashed with religion, primarily the JudaeoChristian beliefs, and specifically how evolutionary biology has added to the disruption of religious complacency, most notably in the 19th century. There are many titles, everyone seems to have some point of view. The first intellectual tsunami that evolution created was against the fracturing bedrock of religion. Take for instance a little book by J.B. Dimbleby titled The Date of Creation, published in 1902. ${ }^{3}$ Dimbleby adamantly defends, on rather a lame scientific basis, the six literal days of creation in Genesis and has little praise for the work of nonconformists like Darwin and others. In reading this book it is obvious that its author has little comprehension of the basic tenets of science and its methodology (still symptomatic of today's "scientific creationist"). But even in the heyday of evolutionary discussions and debates not all religious thinkers were as acidic in their examinations. I recently found a glowing review of Darwin in a book written by Rev. Thomas Guard in his Lectures and Addresses published in 1883. ${ }^{8}$ Here Darwin is compared to the greatness of Emerson and Longfellow (all of whom died in the same year, 1882). Darwin, it is said "loved truth; no doubt of this. Any price would he pay for a fact. He valued them, for he knew how rare they were."

I usually walk by the political section knowing full well that evolution has been consumed and regurgitated in some unrecognizable form to 
support one ideology or another. The same passing glance covers the psychology section even though I know Freud mumbled some words on evolution.

History is a section I used to pass by without much hesitation, but lately $i$ have even ventured into this section of the book store. At a time when church and state were more comfortable bedfellows than today the concept of evolution had a disturbing impact on 19th century society. This can be seen, for example, within a few chapters of E.L. Woodward's The Age of Reform, 1815-1870. ${ }^{18}$

As you can see, if given a general topic, in this case evolution, one can find the obvious titles, but with a little searching you can also discover little gems that link your desired theme throughout the store (or library). This is because no antiquarian book store has the same classification scheme. Books come and go too quickly to follow the library system. Most of these titles, though commonly linked by one theme, can be intermixed almost anywhere in a book shop. Books on creationism can be found in either the science, law, or religion sections; human evolution can be found in the anthropology/archaeology section as well as in general science.

Tired, I am now literarily ballooned. Eyes and brain full of titles I searched, bending high and low between the cramped aisles. I may have come to the store with a specific title or subject to search but leave with unexpected treasures. And, expectation soon grows knowing that many of the bocks l've purchased will be replaced with new, old books. The search will begin again, soon.

For me, these regular treks broaden my perception of the work I do - the biggest threat to myself is becoming too narrow of scope, specializing in one obscure area of our earth's past inhabitants. I am humble in the presence of almost any published volume, whatever the idea or message the pages convey because the authors have extended an idea from the safe solitude of an individuals mind to the critiques or applause of the intended readers. The above titles are but a few examples of such works.

Postscript For one who usually doesn't like surprises the following event I endured with mixed emotions. Several years ago I came across the title of an Agatha Christie novel Ordeal by Innocence, about a Canadian palaeontologist, Dr. Calgary, who on a stopover in England returning from collecting trip from the Antarctic, winds up using his deductive skills as a scientist to solve a murder in which he has become embroiled. ${ }^{1}$ Searching high and low I couldn't find a copy of it. I didn't care what condition, edition, paperback or hard cover, I just wanted a copy. Then I discovered a first edition, and though I paid a pretty penny for it I was happy my search was over. Not more than a month later I was browsing through some shops in a small mall in Edmonton, killing time before the banks opened (so I could purchase books) and strolled into one of those commercial used book shops, you know, the ones that have the bulk of their stock in Harlequin Romances. At the far end of the shop, facing me at eye level was a relatively recent paperback version of Ordeal by Innocence. I am sure, in some alternate dimension, the tattered book had a smirking smile because it knew I had already dented my wallet by purchasing an original edition. Nevertheless, I bought it for the grand sum of $\$ 1.25$ and walked away feeling somewhat victorious. 
1. CHRISTIE, A. 1958. Ordeal by innocence. Collins Clear-Type Press, London. $256 \mathrm{pp}$.

2. CZERKAS, S.M. AND D.F. GLUT. Dinosaurs, mammoths, and cavemen. E.P. Dutton, New York. 120 pp.

3. DIMBLEBY, J.B. 1902. The date of creation. E. Nister, London. 230 pp.

4. DOYLE, A.C. 1984. The illustrated Sherlock Holmes treasury. Chatham River Press, New York. 808 pp.

5. FOWLES, J. 1981. The French lieutenant's woman. The New American Library of Canada, Scarborough. 366 pp.

6. FRANK, P. 1957. Philosophy of science. Prentice Hall, Englewood Cliffs, New Jersey. 394 pp.

7. GINGER, R. 1974. Six days or forever? Oxford Univ. Press, New York. $258 \mathrm{pp}$.

8. GUARD, T. 1883. Lectures and addresses. Phillips and Hunt, New York, $370 \mathrm{pp}$.

9. KUHN, T. 1970. The structure of scientific revolutions (second ed.). University of Chicago Press, Chicago. $210 \mathrm{pp}$.
10. LAWRENCE, J. and R.E. LEE. 1985. Inherit the wind. Bantam Books, Toronto. $115 \mathrm{pp}$.

11. LEATHERDALE, W. 1983. The influence of Darwinism on English literature and literary ideas. Pp. 1-26 in: The wider domain of evolutionary thought, D. Oldroyd and I. Langham, eds. D. Reidel Publishing Company.

12. PEARSON, H. 1946. Conan Doyle. Guild Books, London. 207 pp.

13. RUDWICK, M.J.S. 1992. Scenes from deep time. Univ. of Chicago Press, Chicago. 280 pp.

14. RUSE, M. 1979. The Darwinian revolution. Univ. of Chicago Press, Chicago. $320 \mathrm{pp}$.

15. 1989. The Darwinian paradigm. Routledge, New York. 299 pp.

16. SHAW, G.B. 1987. Back to Methuselah. Penguin Books, New York. 319 pp.

17. STONE, I. 1989. Clarence Darrow for the defense. Doubleday, Toronto. 570 pp.

18. WOODWARD, E.L. 1938. The age of reform 1815-1870. Oxford Univ. Press, New York. 656 pp.

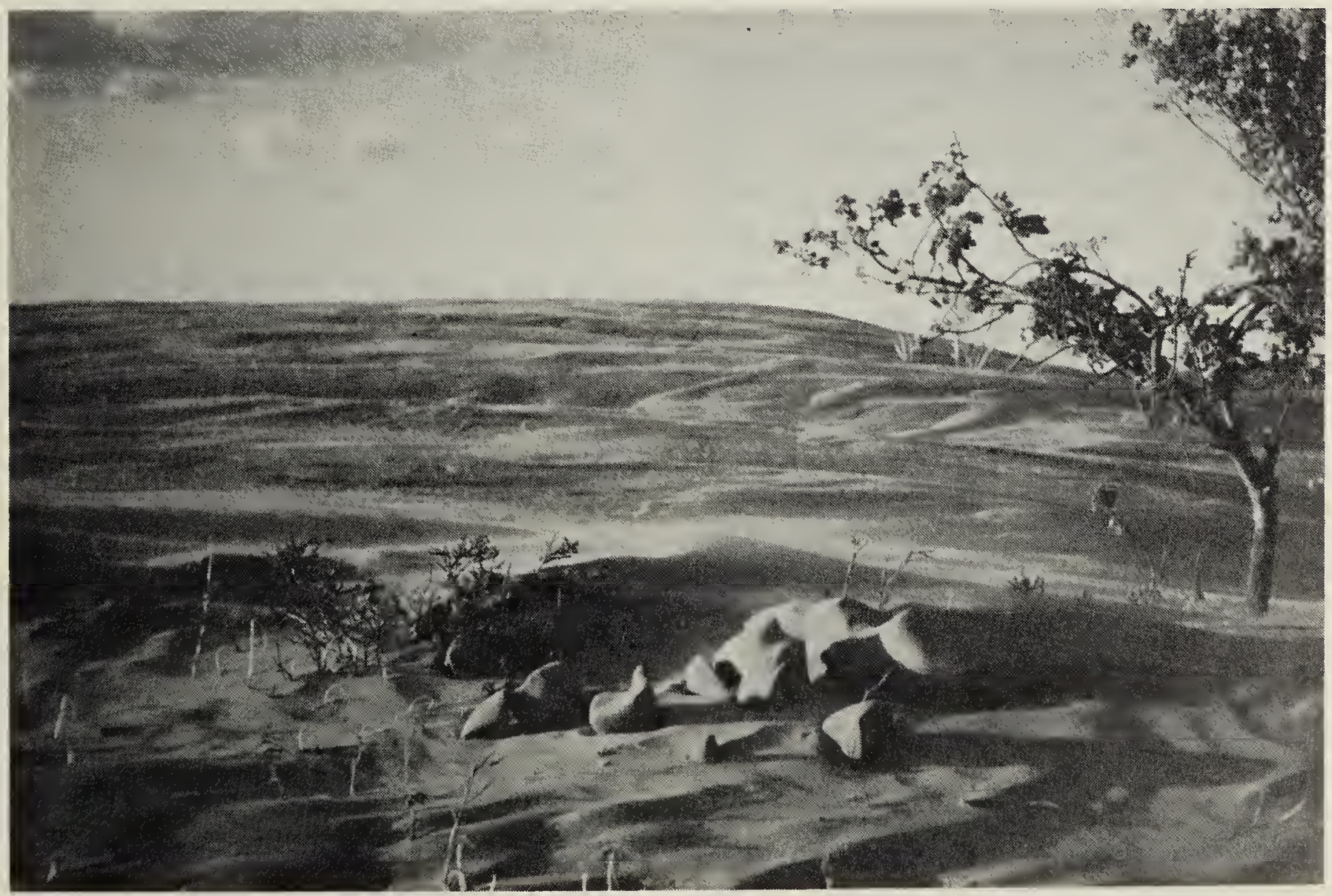

Wind sculpted sand dunes in the Great Sand Hills south of Sceptre, SK. 